\title{
Characteristics and Transformation Mechanism of Nonmetallic Inclusions in 304 Stainless Steel during Heat Treatment at $1250{ }^{\circ} \mathrm{C}$
}

\author{
Wen-Sheng Yang ${ }^{1}$, Shuai Liu ${ }^{1}$, Shao-Wei Han ${ }^{2}$, Jia-Wei Wang ${ }^{3}$, Jing Guo ${ }^{1, *}$, Yan Yan ${ }^{1}$ and \\ Han-Jie Guo ${ }^{1}$ \\ 1 School of Metallurgical and Ecological Engineering, University of Science and Technology Beijing (USTB), \\ Beijing 100083, China; yws3179608@163.com (W.-S.Y.); 1sls1226@163.com (S.L.); \\ b20160095@xs.ustb.edu.cn (Y.Y.); guohanjie@ustb.edu.cn (H.-J.G.) \\ 2 Steelmaking Department, Beijing Shougang Co., Ltd, Qian'an 064400, China; hanshaowei2016@163.com \\ 3 Material Research and Surface Engineering Research Center, Dongfang Electric Corporation Dongfang Turbine Co., \\ LTD, Deyang 618000, China; wangjiaweistudy@gmail.com \\ * Correspondence: guojing@ustb.edu.cn; Tel.:+86-010-15801530260
}

Received: 22 September 2020; Accepted: 23 November 2020; Published: 27 November 2020

check for updates

\begin{abstract}
Evolutions of two typical types of nonmetallic inclusions, i.e., inclusions based on $\mathrm{CaO}-\mathrm{SiO}_{2}-\mathrm{Al}_{2} \mathrm{O}_{3}$ and $\mathrm{MnO}-\mathrm{SiO}_{2}-\mathrm{Al}_{2} \mathrm{O}_{3}$ of 304 stainless steel were investigated in laboratory-scale experiments under isothermal heat treatment at $1250{ }^{\circ} \mathrm{C}$ for $0,30,60$ and $120 \mathrm{~min}$. Results show inclusion population density increases at the first stage and then decreases while their average size decreases and then increases. Moreover, almost no $\mathrm{Cr}_{2} \mathrm{O}_{3}$ content within the inclusion before the heat treatment, but $\mathrm{Cr}_{2} \mathrm{O}_{3}$ content increases gradually along with increasing heat treatment time. Furthermore, the increasing of $\mathrm{Cr}_{2} \mathrm{O}_{3}$ content in the inclusions would increase their melting points and reduce their plasticities. The experimental results and thermodynamic analysis indicate that there are three steps for inclusion evolution during the heat treatment process, in which Ostwald ripening plays an important role in inclusion evolution, i.e., inclusions grow by absorbing the newly formed small-size $\mathrm{MnO}-\mathrm{Cr}_{2} \mathrm{O}_{3}$ inclusions.
\end{abstract}

Keywords: nonmetallic inclusion; heat treatment process; Ostwald ripening; stainless steel

\section{Introduction}

There are two main types of no-inclusions in Si-killed stainless steel are $\mathrm{CaO}-\mathrm{SiO}_{2}-\mathrm{Al}_{2} \mathrm{O}_{3}$-based and $\mathrm{MnO}-\mathrm{SiO}_{2}-\mathrm{Al}_{2} \mathrm{O}_{3}$-based systems [1-5]. They have different properties and different effects on the surface quality of stainless steel strips. Researchers [1-10] found that an effective way to improve the surface quality of stainless steel strip by controlling the nonmetallic inclusion as plasticity $\mathrm{MnO}-\mathrm{SiO}_{2}-\mathrm{Al}_{2} \mathrm{O}_{3}$-based inclusion instead of $\mathrm{CaO}-\mathrm{SiO}_{2}-\mathrm{Al}_{2} \mathrm{O}_{3}$-based ones. This could be realized by using different basicity refining slags and $[\mathrm{Al}]_{\mathrm{s}}$ contents during the smelting process. The melting points of $\mathrm{CaO}-\mathrm{SiO}_{2}-\mathrm{Al}_{2} \mathrm{O}_{3}$ and $\mathrm{MnO}-\mathrm{SiO}_{2}-\mathrm{Al}_{2} \mathrm{O}_{3}$ inclusions, in particular the latter, are relatively low and the liquid phase is likely to present at the soaking process, which is before the rolling process. In addition, the high $\mathrm{Cr}$ content $(18 \mathrm{wt} \%)$ containing in 304 stainless steel is more likely to react with the liquid inclusions or solid-liquid mixes in the steel during the soaking process. This reaction will change the morphology, size, composition, and even crystal structure of the inclusions. Correspondingly, the mechanical properties of inclusions and their effects on the final products will be perhaps changed as well. Therefore, it is important to investigate the evolution behaviors of two main types of noninclusion during the soaking process. 
Many researchers have noted that the nonmetallic inclusion would change in shape, size, and/or composition during heat treatment. Takahashi et al. [11] reported the inclusion in $18 \mathrm{Cr}-8 \mathrm{Ni}$ stainless steel would evolve from $\mathrm{CaO}-\mathrm{SiO}_{2}-\mathrm{Al}_{2} \mathrm{O}_{3}$ to $\mathrm{MnO}-\mathrm{Cr}_{2} \mathrm{O}_{3}$ during heat treatment at $800{ }^{\circ} \mathrm{C}$ to $1200{ }^{\circ} \mathrm{C}$. Takano et al. [12] found that a large number of $\mathrm{MnO}-\mathrm{Cr}_{2} \mathrm{O}_{3}$ inclusions precipitated during heat treatment and they could somehow pin austenite grain boundary in a $17 \mathrm{Cr}-9 \mathrm{Ni}$ stainless steel. Shibata et al. $[13,14]$ discovered that inclusion transferred from $\mathrm{MnO}-\mathrm{SiO}_{2}$ to $\mathrm{MnO}-\mathrm{Cr}_{2} \mathrm{O}_{3}$ during heat treatment and they also discussed the effects of $\mathrm{Si}, \mathrm{Mn}, \mathrm{Ni}$ and $\mathrm{Cr}$ contents on the evolutions of inclusions. Taniguchi et al. [15] investigated the inclusion variation in martensitic stainless steel and proposed three steps for nonmetallic inclusion phase transformation during heat treatment. Ren et al. [16] also reported that the $\mathrm{MnO}-\mathrm{SiO}_{2}$ type inclusion would transform to $\mathrm{MnO}-\mathrm{Cr}_{2} \mathrm{O}_{3}$ spinel-type inclusion during heat treatment, and they proposed that the modification was as $\mathrm{Cr}$ reduced the $\mathrm{SiO}_{2}$ in $\mathrm{SiO}_{2}-\mathrm{MnO}$-based inclusion.

Our previous work [17] has investigated the plasticized $\mathrm{MnO}-\mathrm{Al}_{2} \mathrm{O}_{3}-\mathrm{SiO}_{2}$-based inclusion evolution during heat treatment and found that the chemical reaction between $\mathrm{Cr}$ and $\mathrm{SiO}_{2}$ as well as Ostwald ripening plays a significant role in the inclusion behavior during heat treatment. Those results indicate that behaviors of nonmetallic inclusion during the soaking process are still not fully understood. For example, the differences between two main types of inclusions, i.e., $\mathrm{CaO}-\mathrm{SiO}_{2}-\mathrm{Al}_{2} \mathrm{O}_{3}$-based and $\mathrm{MnO}-\mathrm{SiO}_{2}-\mathrm{Al}_{2} \mathrm{O}_{3}$-based during the industrial soaking process (soaking temperature and time are $1250{ }^{\circ} \mathrm{C}$ and $120 \mathrm{~min}$, respectively) and their evolution mechanisms are rarely reported. Furthermore, the properties of the two types of inclusions after the soaking process are not clarified.

In the present study, two 304 steel slabs, containing mainly $\mathrm{CaO}-\mathrm{SiO}_{2}-\mathrm{Al}_{2} \mathrm{O}_{3}$-based and $\mathrm{MnO}-\mathrm{SiO}_{2}-\mathrm{Al}_{2} \mathrm{O}_{3}$-based inclusions, respectively, were manufactured and isothermal heat treatment for the different time at $1250{ }^{\circ} \mathrm{C}$ to reveal the nonmetallic inclusion transformation process during the industrial soaking process. Furthermore, a thermodynamic analysis was performed and Ostwald ripening was introduced to explain the inclusion evolution mechanism.

\section{Materials and Methods}

The steel specimens were taken from two continuous casting slabs of industrial 304 stainless steel that were smelted by two basicity refining slags: steel A was smelted by a ladle furnace (LF) refining slag with basicity $\left(\mathrm{CaO} / \mathrm{SiO}_{2}\right)$ approximating 1.8 and corresponding refining slag basicity of steel B in LF was 1.5. The steel compositions and refining slag compositions were shown in Tables 1 and 2, respectively. Moreover, the inclusions in the slabs of steel $\mathrm{A}$ and steel $\mathrm{B}$ were confirmed as mainly as $\mathrm{CaO}-\mathrm{SiO}_{2}-\mathrm{Al}_{2} \mathrm{O}_{3}$-based and $\mathrm{MnO}-\mathrm{SiO}_{2}-\mathrm{Al}_{2} \mathrm{O}_{3}$-based inclusion by scanning electron microscopy/energy-dispersive spectroscopy (SEM/EDS) before heat treatment, as shown in Figures 1 and 2, respectively.

Table 1. 304 stainless steel composition in the present experiment, mass \%.

\begin{tabular}{cccccccccc}
\hline No. & $\mathbf{C}$ & $\mathbf{S i}$ & $\mathbf{M n}$ & $\mathbf{P}$ & $\mathbf{S}$ & $\mathbf{C r}$ & $\mathbf{N i}$ & Als/ppm & T.O/ppm \\
\hline A & 0.048 & 0.415 & 1.164 & 0.032 & 0.0015 & 17.98 & 8.17 & 19 & 33 \\
B & 0.047 & 0.431 & 1.204 & 0.032 & 0.0012 & 18.15 & 8.01 & 9 & 35 \\
\hline \multicolumn{8}{c}{ Note: T.O represents total oxygen in stainless steel samples. }
\end{tabular}

Table 2. Top slag composition at the finial LF refining in the present experiment, mass \%.

\begin{tabular}{cccccccccc}
\hline No. & $\mathrm{CaO}$ & $\mathrm{SiO}_{2}$ & $\mathrm{Al}_{2} \mathrm{O}_{\mathbf{3}}$ & $\mathbf{M g O}$ & $\mathrm{CaF}_{2}$ & $\mathrm{Cr}_{\mathbf{2}} \mathrm{O}_{3}$ & $\mathrm{TiO}_{\mathbf{2}}$ & $\mathrm{MnO}$ & $\mathrm{FeO}$ \\
\hline $\mathrm{A}$ & 45.9 & 26.2 & 2.9 & 6.7 & 16.7 & 0.10 & 0.49 & 0.07 & 0.08 \\
$\mathrm{~B}$ & 46.4 & 30.3 & 2.1 & 7.7 & 12.4 & 0.27 & 0.31 & 0.32 & 0.26 \\
\hline
\end{tabular}

The steel specimens were machined into $15 \mathrm{~mm} \times 15 \mathrm{~mm} \times 15 \mathrm{~mm}$ cubic samples and were used for laboratory-scale isothermal heat-treated experiments. The heat treatment experiments were 
carried out in a muffle furnace with four $\mathrm{MoSi}_{2}$ elements (molybdenum silicide bar) in a $200 \mathrm{~mL} / \mathrm{min}$ argon atmosphere. Firstly, the temperature was raised to $1250{ }^{\circ} \mathrm{C}$ by a heating rate of $10 \mathrm{~K} / \mathrm{min}$. Then, the temperature was held for 0, 30, 60 and $120 \mathrm{~min}$ for the steel samples marked as \#1,\#2, \#3 and \#4, respectively. The samples were quenched in the water after the heat treatment process. The quenched steel samples were ground and mirror polished for SEM-EDS observation. At the same time, inclusion analysis system equipped with SEM and EDS (EV018-INCAsteel, Oxford Instruments, Oxfordshire, UK) was applied to automatically analyse their morphology (i.e., aspect ratio), size and composition evolution during heat treatment on an analysed area of $5 \mathrm{~mm} \times 5 \mathrm{~mm}$. The working distance difference between the highest point and the lowest point of the sample detection area had been controlled to less than $5 \mu \mathrm{m}$. Otherwise it would exceed the auto-focus ability of the equipment. It should be pointed out that $\mathrm{Fe}$ and $\mathrm{Ni}$ in the inclusions detected by energy disperse spectroscopy (EDS) were removed to minimize the effects of steel matrix on inclusion composition, and some unclear spots were selected and excluded before the present inclusion analysis. In addition, the thermodynamic analysis was performed to study the inclusion transformation mechanism with the help of thermodynamic software FactSage 7.2 [18].

\section{Results}

Figures 1 and 2 are typical inclusion morphologies in steel A and Steel B, respectively. In addition, their melting points calculated by the submodule Equilib of FactSage 7.2 according to their compositions, are also listed in the Tables 3 and 4, respectively. The morphologies of inclusions in the two steel samples are mainly spherical, and their sizes are mainly lower than $5 \mu \mathrm{m}$. However, the inclusion components and their corresponding melting points are significantly different. As shown in the Table 3 , the inclusions in steel $\mathrm{A}$ are mainly composed of $\mathrm{CaO}, \mathrm{SiO}_{2}$ and $\mathrm{Al}_{2} \mathrm{O}_{3}$, as well as small amounts of $\mathrm{MnO}, \mathrm{MgO}$ and/or $\mathrm{TiO}_{2}$. Calculated by FactSage 7.2, the melting points of those inclusions are between $1391{ }^{\circ} \mathrm{C}$ to $2050{ }^{\circ} \mathrm{C}$, and the average melting point is $1561{ }^{\circ} \mathrm{C}$, which is much higher than the open-rolling temperature region (i.e., $1150-1250{ }^{\circ} \mathrm{C}$ ).

Compared with the inclusions in steel $\mathrm{A}, \mathrm{CaO}$ contents of the inclusions in steel $\mathrm{B}$ are much less while the $\mathrm{MnO}$ contents are much more. Furthermore, the $\mathrm{Al}_{2} \mathrm{O}_{3}$ contents in the inclusions are much less as well. The melting points of the inclusions in steel $\mathrm{B}$ are between $1143^{\circ} \mathrm{C}$ to $1479{ }^{\circ} \mathrm{C}$, and their average is $1238^{\circ} \mathrm{C}$ that is close to the open-rolling temperature region, indicating the inclusions are well plasticized since they are likely to soften at the rolling temperature. In a word, the inclusion in steel $\mathrm{A}$ is $\mathrm{CaO}-\mathrm{SiO}_{2}-\mathrm{Al}_{2} \mathrm{O}_{3}$-based, and have a relative high melting point due to being smelted by the high basicity refining slag. The inclusion in steel $\mathrm{B}$ is plasticized $\mathrm{MnO}-\mathrm{SiO}_{2}-\mathrm{Al}_{2} \mathrm{O}_{3}-\mathrm{based}$, and have a low melting point due to the low basicity slag refining.

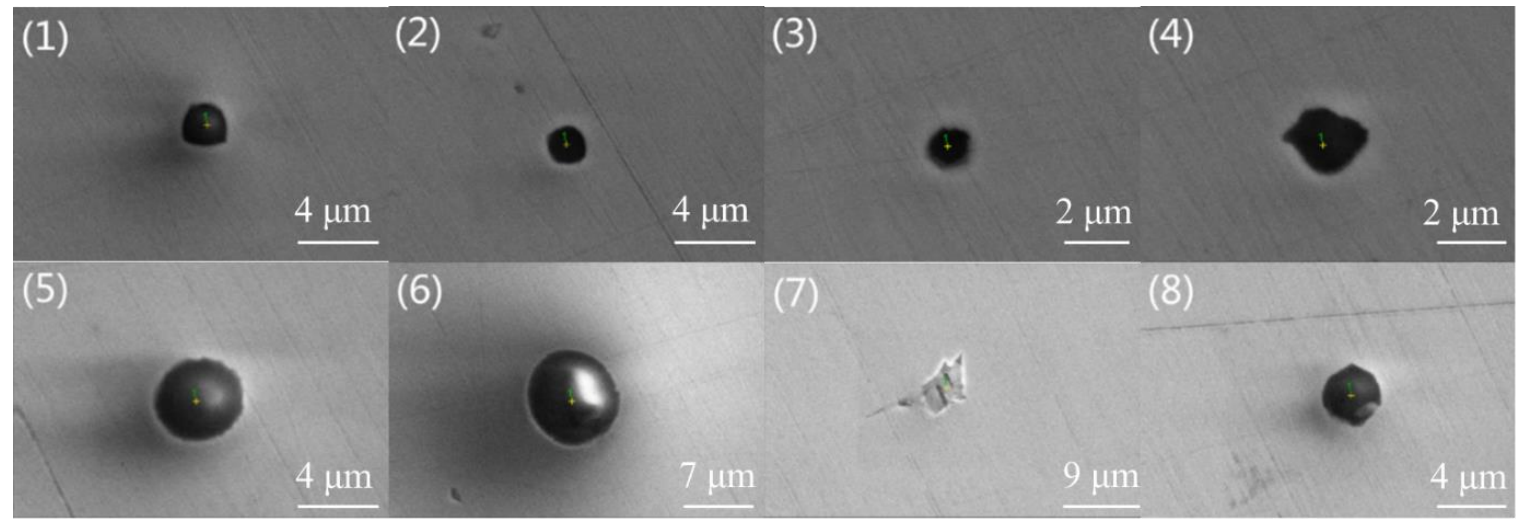

Figure 1. Typical morphologies of nonmetallic inclusions in the slab A. (1-4) small size inclusions; (5-8) large size inclusions. 
Table 3. Compositions of typical inclusions in Figure 1.

\begin{tabular}{cccccccccc}
\hline NO. & $\mathbf{C a O} / \%$ & $\mathbf{S i O}_{2} / \%$ & $\mathbf{M g O} / \%$ & $\mathbf{A l}_{\mathbf{2}} \mathbf{O}_{3} / \%$ & $\mathbf{M n O} \%$ & $\mathrm{CaS} / \%$ & $\mathrm{TiO}_{2} / \%$ & $\mathrm{D} / \mu \mathrm{m}$ & $\mathrm{Tf} /{ }^{\circ} \mathbf{C}$ \\
\hline 1 & 3 & 3 & 15 & 61 & 16 & 0 & 2 & 2.00 & 1651 \\
2 & 26 & 28 & 6 & 30 & 5 & 0 & 4 & 1.20 & 1458 \\
3 & 24 & 29 & 7 & 35 & 4 & 0 & 0 & 1.24 & 1511 \\
4 & 20 & 21 & 4 & 35 & 17 & 0 & 4 & 2.61 & 1496 \\
5 & 21 & 25 & 10 & 34 & 5 & 0 & 5 & 4.27 & 1523 \\
6 & 41 & 29 & 9 & 19 & 1 & 0 & 0 & 9.80 & 1414 \\
7 & 0 & 0 & 0 & 100 & 0 & 0 & 0 & 10.00 & 2050 \\
8 & 23 & 31 & 5 & 27 & 11 & 3 & 0 & 3.48 & 1391 \\
Average & 20 & 21 & 7 & 43 & 7 & 0 & 2 & 4.33 & 1561 \\
\hline
\end{tabular}

Note: $\mathrm{D}$ presents inclusion diameter and $\mathrm{T}_{\mathrm{f}}$ means the melting point of the inclusion.

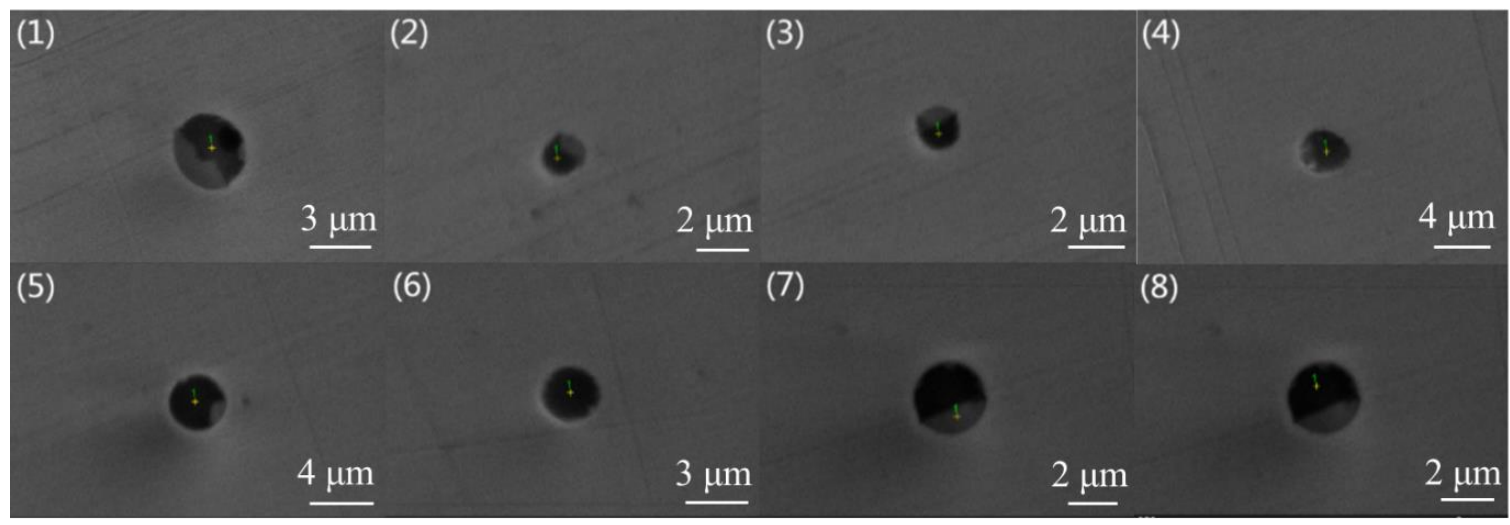

Figure 2. Typical morphologies of nonmetallic inclusions in the slab B. (1-8) small size inclusions (large size inclusions were not found).

Table 4. Compositions of typical inclusions in Figure 2.

\begin{tabular}{cccccccccc}
\hline NO. & $\mathbf{C a O} / \%$ & $\mathrm{SiO}_{2} / \%$ & $\mathbf{M g O} / \%$ & $\mathbf{A l}_{\mathbf{2}} \mathbf{O}_{3} / \%$ & $\mathbf{M n O} / \%$ & $\mathbf{C a S} / \%$ & $\mathrm{TiO}_{2} / \%$ & $\mathbf{D} / \mu \mathrm{m}$ & $\mathbf{T f} /{ }^{\circ} \mathbf{C}$ \\
\hline 1 & 0 & 46 & 0 & 7 & 44 & 4 & 0 & 3.00 & 1213 \\
2 & 0 & 50 & 0 & 19 & 31 & 0 & 0 & 1.25 & 1172 \\
3 & 0 & 42 & 0 & 15 & 40 & 0 & 3 & 1.43 & 1157 \\
4 & 10 & 40 & 16 & 22 & 12 & 0 & 0 & 2.96 & 1363 \\
5 & 5 & 45 & 0 & 21 & 29 & 0 & 0 & 2.80 & 1142 \\
6 & 9 & 44 & 7 & 19 & 22 & 0 & 0 & 2.75 & 1214 \\
7 & 0 & 17 & 0 & 26 & 46 & 0 & 12 & 2.36 & 1479 \\
8 & 3 & 42 & 0 & 19 & 36 & 0 & 0 & 2.36 & 1167 \\
Average & 3 & 41 & 3 & 18 & 32 & 0 & 1 & 2.36 & 1238 \\
\hline
\end{tabular}

Figure $3 \mathrm{a}, \mathrm{b}$ show the average inclusion composition evolution during the heat treatment process of steel A and steel B, respectively. For the steel A as shown in Figure $3 \mathrm{a}$, the average $\mathrm{Cr}_{2} \mathrm{O}_{3}$ and $\mathrm{MnO}$ contents gradually increase with increasing heat treatment time. In contrast, the $\mathrm{CaO}$ and $\mathrm{SiO}_{2}$ contents decrease significantly. The contents of $\mathrm{Al}_{2} \mathrm{O}_{3}$ and $\mathrm{MgO}$ are somewhat fluctuant, and do not show obvious variation during heat treatment. As shown in Figure $3 b$, the change of each component is similar to that of Figure $3 \mathrm{a}$. However, the average $\mathrm{Cr}_{2} \mathrm{O}_{3}$ content of inclusion in steel B increases much more than that in steel $\mathrm{A}$, while the $\mathrm{SiO}_{2}$ content decreases significantly along with the heat treatment time. In a word, during heat treatment, $\mathrm{Cr}_{2} \mathrm{O}_{3}$ and $\mathrm{MnO}$ of the inclusions in the two samples both increase while the $\mathrm{SiO}_{2}$ and $\mathrm{CaO}$ contents decrease. However, there are also some differences between the inclusion composition evolution in the two steel: $\mathrm{Cr}_{2} \mathrm{O}_{3}$ in steel $\mathrm{B}$ increases much more than that in steel $\mathrm{A}$; the $\mathrm{SiO}_{2}$ content in steel B decreases more obviously than in steel A. 
(a)

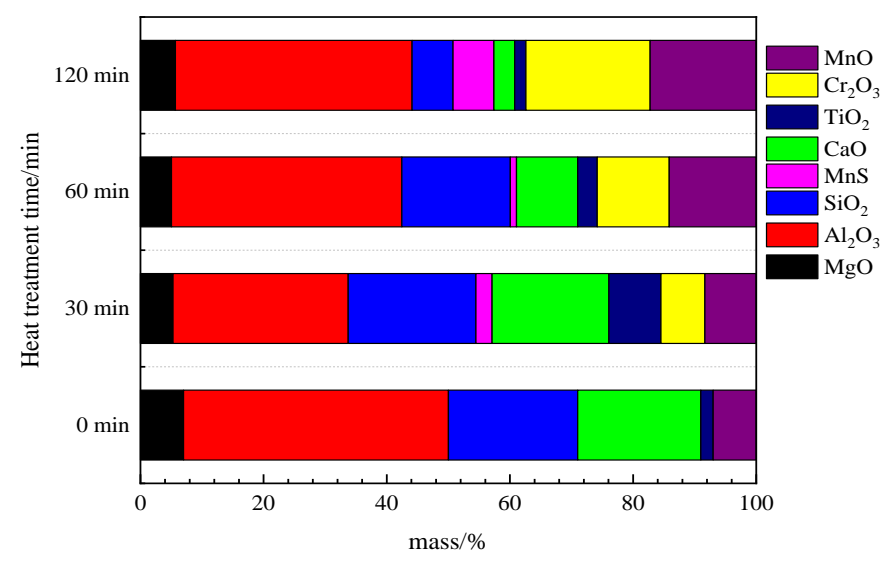

(b)

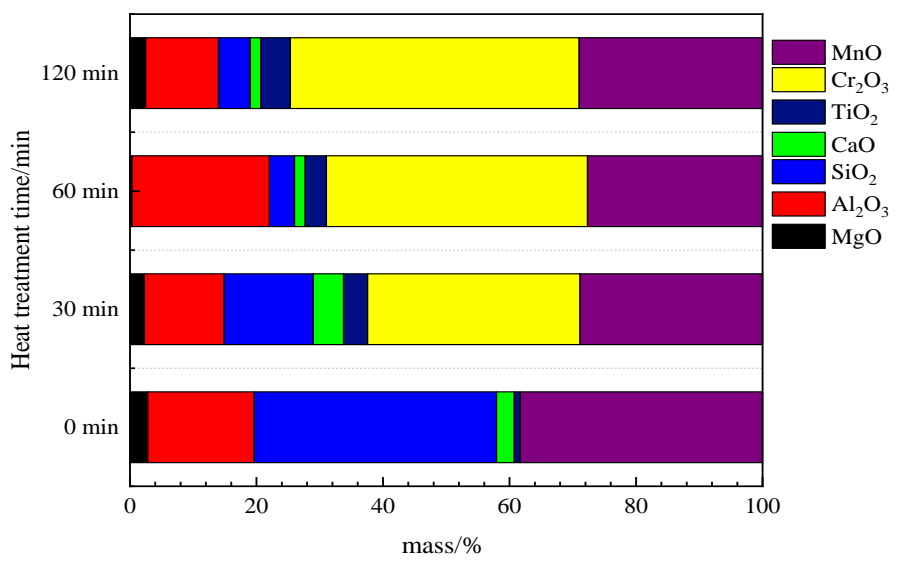

Figure 3. Variations in the average composition of inclusions during heat treatment: (a) steel A, (b) steel B.

Figure 4 shows the variations of the liquid phase and $\mathrm{Cr}_{2} \mathrm{O}_{3}$ content in the inclusion of steel $\mathrm{A}$ and steel $\mathrm{B}$ with the heat treatment time at $1250{ }^{\circ} \mathrm{C}$ calculated by FactSage 7.2 based on the average composition of inclusion. With the $\mathrm{Cr}_{2} \mathrm{O}_{3}$ content increase during heat treatment, $\mathrm{MnO}-\mathrm{Cr}_{2} \mathrm{O}_{3}$ spinel phase in the inclusion increase correspondingly. The MnO- $\mathrm{Cr}_{2} \mathrm{O}_{3}$ spinel phase in the inclusion of steel $\mathrm{B}$ increases much rapidly than that in steel $\mathrm{A}$. In addition, the percentage of the liquid phase in steel A and steel B decreases with increasing heat treatment time, which is due to the change of inclusion composition. Associated with the aforementioned phenomena (Figures 3 and 4), it is therefore indicated that $\mathrm{MnO}-\mathrm{Cr}_{2} \mathrm{O}_{3}$ spinel continuously precipitates during heat treatment.

Figure $5 \mathrm{a}, \mathrm{b}$ show the changes of inclusion population density and average inclusion size during heat treatment in steel A and steel B, respectively. Interestingly, the above indexes in steel A and steel B show a similar tendency. After heat treatment for $30 \mathrm{~min}$, the inclusion population density increases as many small size $\mathrm{Cr}_{2} \mathrm{O}_{3}-\mathrm{MnO}$-based inclusions precipitate during the heat treatment process, and the average inclusion size decreases correspondingly. With increasing heat treatment time, the inclusion population density decreases, and their average size gradually increases. This is because the inclusion growth follows the Ostwald ripening during heat treatment: the small inclusions dissolve and the larger inclusions grow. Ren et al. [16] also observed a similar inclusion number evolution and size distribution, which is consistent with the findings in Figure 5. Those phenomena in the Figure 5 are more popular for inclusion transformation during heat treatment. Compared with steel A, steel B has had an even more volatile ride after 30 min due to the higher transformation speed caused by lower melting points. 

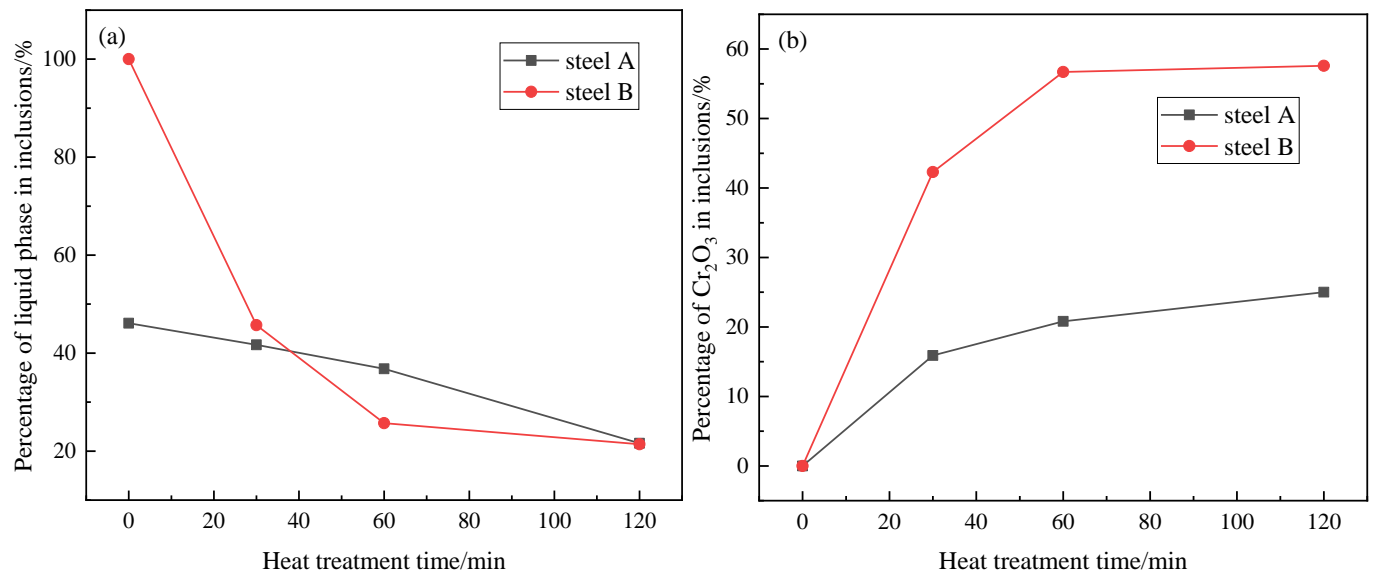

Figure 4. Change of the liquid phase (a) and $\mathrm{Cr}_{2} \mathrm{O}_{3}(\mathbf{b})$ content in the inclusion of steel $\mathrm{A}$ and steel B with the heat treatment time at $1250{ }^{\circ} \mathrm{C}$ calculated by FactSage 7.2.
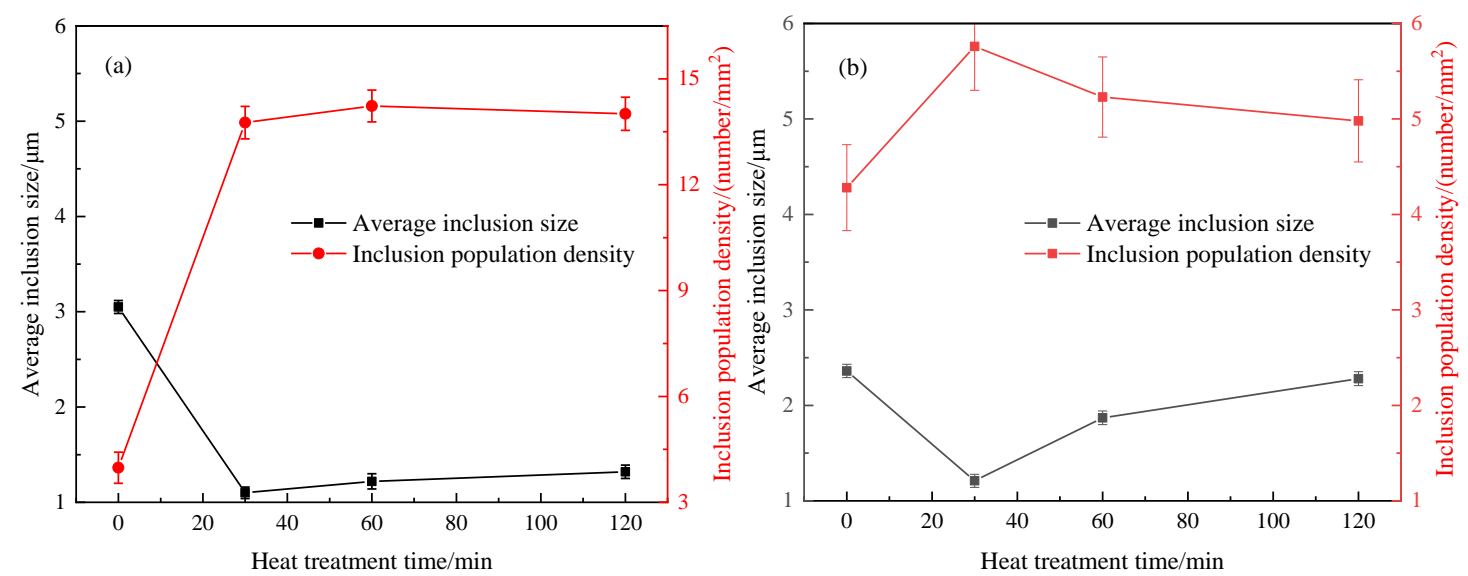

Figure 5. Variations in the population density and average size of inclusions at $1250{ }^{\circ} \mathrm{C}$ in steel A (a) and steel B (b).

Figures 6 and 7 show SEM-mapping images of some typical inclusions in the steel samples at different stages of the heat treatment process. At the beginning of the heat treatment as shown in Figures $6 \mathrm{a}$ and $7 \mathrm{a}$, no $\mathrm{Cr}$ oxide-concentrated regions were found within all inclusions. The differences are that: (1) there is a triangular Al-concentrated region in the left part of inclusion of Figure 6a while Al distributes homogeneously within the inclusion in Figure 7a; and (2) very little Mn was detected in the inclusion in Figure 6a, while much more Mn content was detected uniformly distributed in the inclusion in Figure 7a. As shown in Figures $6 \mathrm{~b}$ and $7 \mathrm{~b}$, some quadrate $\mathrm{Cr}_{2} \mathrm{O}_{3}-\mathrm{MnO}-\mathrm{Al}_{2} \mathrm{O}_{3}$-concentrated regions were observed in the outer layer within the inclusion, and the other parts are $\mathrm{CaO}-\mathrm{SiO}_{2}$ became enriched in the composition after heat treatment for $30 \mathrm{~min}$. However, the inclusions in Figures $6 \mathrm{c}$ and $7 \mathrm{c}$ are different: a faceted $\mathrm{Cr}_{2} \mathrm{O}_{3}-\mathrm{MnO}-\mathrm{Al}_{2} \mathrm{O}_{3}$-concentrated core with a light color in the center of inclusion listed in Figure 6c, while most of inclusions were $\mathrm{Cr}_{2} \mathrm{O}_{3}-\mathrm{MnO}$-concentrated region in the outer layer and only a small $\mathrm{CaO}-\mathrm{SiO}_{2}$-concentrated region in the top left corner of inclusion in Figure 7c. Interestingly, some $\mathrm{Cr}_{2} \mathrm{O}_{3}-\mathrm{MnO}-\mathrm{Al}_{2} \mathrm{O}_{3 \text {-conce }}$ trated regions were inserted in the inclusion in steel A after heat treatment for $120 \mathrm{~min}$ as shown in Figure 6d. In the contrast, a $\mathrm{Cr}_{2} \mathrm{O}_{3}-\mathrm{MnO}-\mathrm{Al}_{2} \mathrm{O}_{3}$-concentrated core wrapped by a ring-like $\mathrm{CaO}-\mathrm{SiO}_{2}$-concentrated region was observed in the inclusion of steel B after heat treatment for $120 \mathrm{~min}$ as shown in Figure $7 \mathrm{~d}$. In short, there are some interesting similar behaviors of the inclusions evolution during heat treatment, although the compositions at the beginning are quite different. $\mathrm{The} \mathrm{Cr}_{2} \mathrm{O}_{3}$ contents in the inclusions are increasing with increasing heat treatment time, but the $\mathrm{Cr}$ element does not always diffusion from the outer layer to the inner part; $\mathrm{Cr}_{2} \mathrm{O}_{3}-\mathrm{MnO}$ or $\mathrm{Cr}_{2} \mathrm{O}_{3}-\mathrm{MnO}-\mathrm{Al}_{2} \mathrm{O}_{3}$-enriched regions and the $\mathrm{CaO}-\mathrm{SiO}_{2}$-concentrated 
region seem incompatible and complementary among the inclusions in most inclusions in the two steels. The difference is that the Mn element concentration of inclusion in steel A is much less than that of inclusions in steel B, which agrees with the inclusion composition in Figure 3.
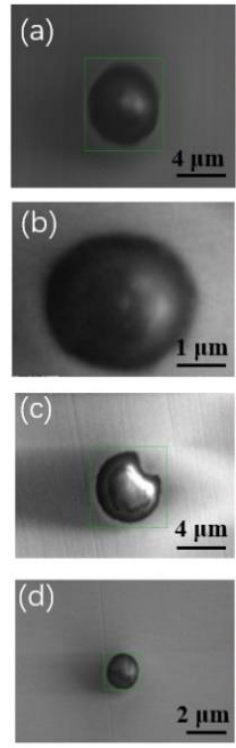
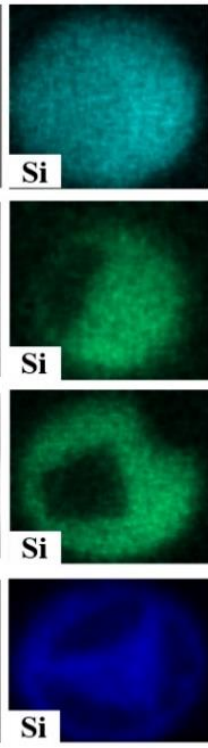
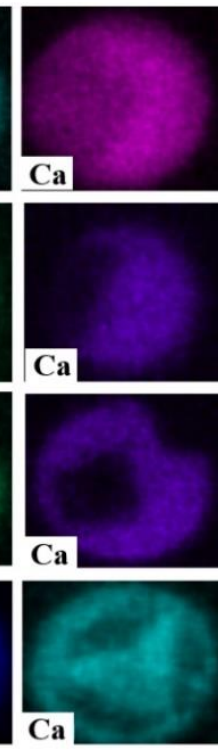
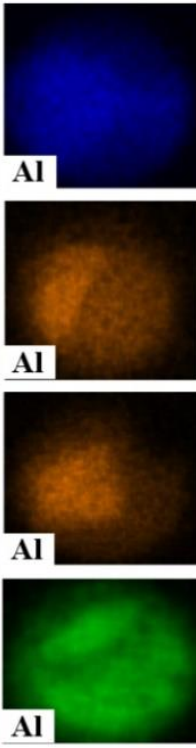
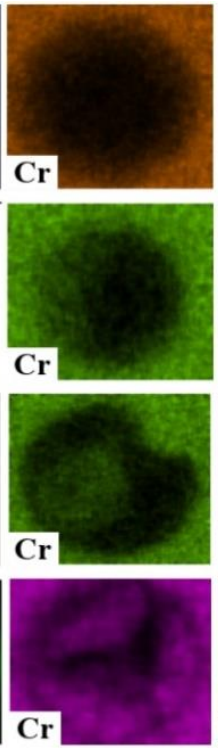
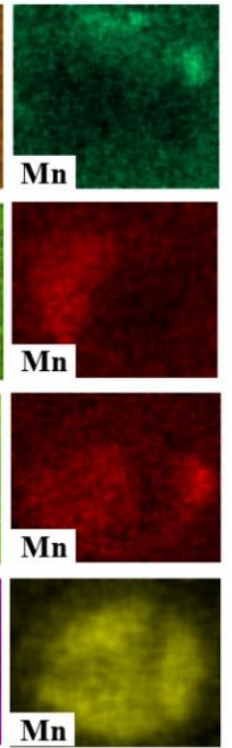

Figure 6. SEM-mapping of some typical inclusions after heat treatment for different time in steel A: (a) \#1, $0 \mathrm{~min}$; (b) \#2, 30min; (c) \#3, $60 \mathrm{~min}$ and (d) \#4,120 min.
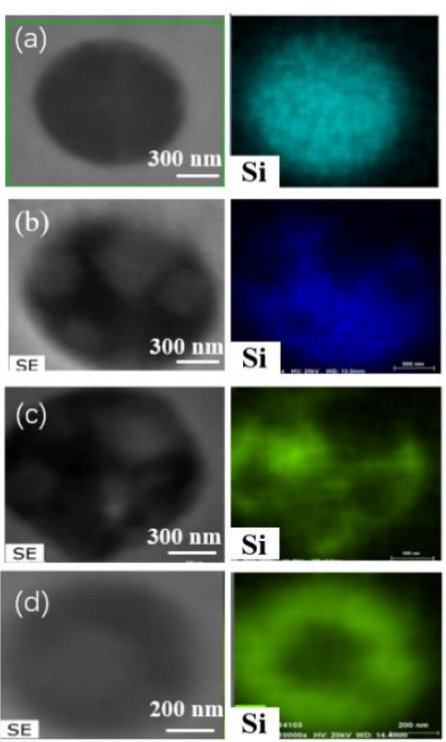
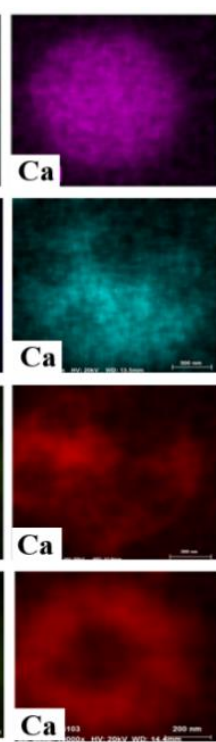
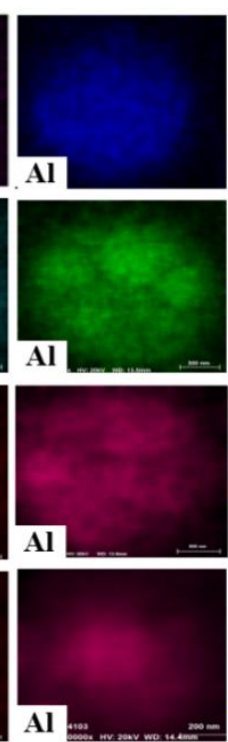
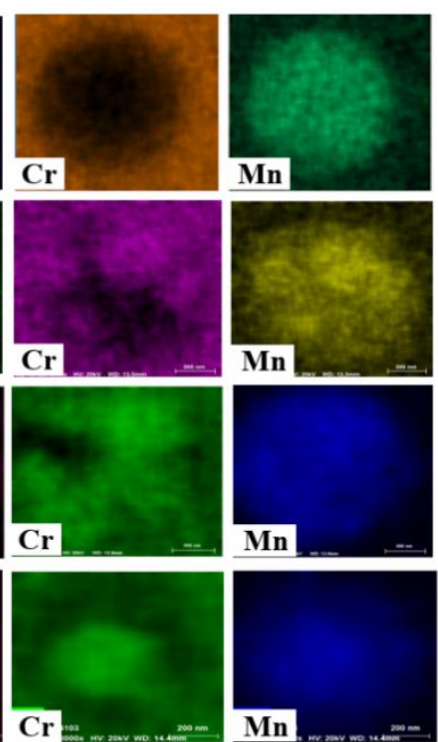

Figure 7. SEM-mapping of some typical inclusions after heat treatment for different time in steel B:

(a) \#1, $0 \mathrm{~min}$; (b) \#2, 30min; (c) \#3, 60 min and (d) \#4,120 min.

\section{Discussion}

Thermodynamic calculated results (Figure 4) and the experimental results show a large number of $\mathrm{Cr}_{2} \mathrm{O}_{3}-\mathrm{MnO}$ tetragonal spinel contained some amount of $\mathrm{Al}_{2} \mathrm{O}_{3}$ would precipitate during heat treatment process. They result in the change of inclusion composition as shown in Figure 3 and inclusion size and density, as shown in Figure 5.

According to the density functional theory calculations $[19,20]$, the solute atoms can enter the oxide defect and produce a mixed oxide structure, which indicates that $\mathrm{Cr}$ atoms may have a chemical reaction with oxygen in inclusions. Some researchers $[14,16]$ developed the idea that the formation of 
$\mathrm{MnCr}_{2} \mathrm{O}_{4}$ spinel during the heat treatment process is due to the reaction between $\mathrm{Cr}$ in the solid steel matrix and $2 \mathrm{MnO} \cdot \mathrm{SiO}_{2}$-type inclusion, as shown in Equation (1).

$$
2[\mathrm{Cr}]+2 \mathrm{MnO} \cdot \mathrm{SiO}_{2}=\mathrm{MnO} \cdot \mathrm{Cr}_{2} \mathrm{O}_{3}+[\mathrm{Mn}]+2[\mathrm{Si}]
$$

In fact, the $\mathrm{Cr}$ in steel matrix has the possibilities to react with $\mathrm{MnO}, \mathrm{SiO}_{2}, \mathrm{Al}_{2} \mathrm{O}_{3}$ and even $\mathrm{CaO}$, thus the thermodynamic analysis among these chemical reactions should be performed to understand the inclusion evolution mechanism.

The reaction between $[\mathrm{Cr}]$ and $(\mathrm{MnO})$ and its standard Gibbs energy $\Delta G^{\theta}$ are expressed as Equations (2) and (3) [21]. Equation (4) is the Gibbs free energy $\Delta G_{(\mathrm{MnO})}$ of the actual reaction.

$$
\begin{gathered}
2[\mathrm{Gr}]+3(\mathrm{MnO})=\left(\mathrm{Cr}_{2} \mathrm{O}_{3}\right)+3[\mathrm{Mn}] \\
\Delta G^{\theta}=-84310+40.035 T \\
\Delta G_{(\mathrm{MnO})}=\Delta G^{\theta}+R T \ln \left(\frac{a_{[\mathrm{Mn}]}^{3} a_{\mathrm{Cr}_{2} \mathrm{O}_{3}}}{a_{[\mathrm{Cr}]}^{2} a_{\mathrm{MnO}}}\right)
\end{gathered}
$$

where $R$ is gas constant, $8.314 \mathrm{~J} /(\mathrm{mol} \cdot \mathrm{K}) ; T$ represents temperature (i.e., $1523 \mathrm{~K}) ; a_{[\mathrm{Mn}]}$ and $a_{[\mathrm{Cr}]}$ are the element activity in steel matrix relative to $1 \%$ standard state; $a_{\mathrm{MnO}}$ and indicate the $\mathrm{MnO}$ and $\mathrm{Cr}_{2} \mathrm{O}_{3}$ activities in the inclusion. The $\mathrm{Al}_{2} \mathrm{O}_{3}-\mathrm{SiO}_{2}-\mathrm{MnO}$ inclusions are in liquid phase, or most of them are in liquid at $1523 \mathrm{~K}$; thus the activity of the $\mathrm{MnO}$ and $\mathrm{Cr}_{2} \mathrm{O}_{3}$ are calculated by applying of the thermodynamic software FactSage 7.2 [18].

Similarly, the Gibbs free energies of the other reactions can be obtained according to their corresponding standard Gibbs free energy as shown in Table 5. Table 6 shows the average contents of the two typical inclusions and the corresponding activities calculated by FactSage 7.2.

Table 5. Some possible reactions and their standard Gibbs free energy.

\begin{tabular}{ccc}
\hline Chemical reaction & Standard Gibbs free energy & Reference \\
\hline $2[\mathrm{Cr}]+\frac{3}{2}\left(\mathrm{SiO}_{2}\right)=\mathrm{Cr}_{2} \mathrm{O}_{3}+\frac{3}{2}[\mathrm{Si}]$ & $57350+30.525 \mathrm{~T}$ & {$[21]$} \\
$2[\mathrm{Cr}]+\left(\mathrm{Al}_{2} \mathrm{O}_{3}\right)=\mathrm{Cr}_{2} \mathrm{O}_{3}+2[\mathrm{Al}]$ & $417690-35.975 \mathrm{~T}$ & {$[21]$} \\
$2[\mathrm{Cr}]+3(\mathrm{CaO})=\mathrm{Cr}_{2} \mathrm{O}_{3}+3[\mathrm{Ca}]$ & $170690+357.825 \mathrm{~T}$ & {$[21]$} \\
\hline
\end{tabular}

Table 6. Average inclusion composition and the calculated activities of two typical inclusions at $1250^{\circ} \mathrm{C}$.

\begin{tabular}{ccccc}
\hline & \multicolumn{2}{c}{ SteelA } & \multicolumn{2}{c}{ Steel B } \\
\hline Composition & Content/wt\% & Acticity $\boldsymbol{\alpha}$ & Content/wt $\%$ & Acticity $\boldsymbol{\alpha}$ \\
\hline $\mathrm{Al}_{2} \mathrm{O}_{3}$ & 40.8 & 0.215 & 16.9 & 0.057 \\
$\mathrm{SiO}_{2}$ & 29.6 & 0.204 & 39.5 & 0.280 \\
$\mathrm{MnO}$ & 16.3 & 0.082 & 43.6 & 0.210 \\
$\mathrm{CaO}$ & 13.3 & 0.001 & - & - \\
\hline
\end{tabular}

The activity coefficients $f_{\mathrm{Cr}}$ and $f_{\mathrm{Mn}}$ are calculated by the Wagner formula in Equation (5), where $e_{\mathrm{i}}^{\mathrm{j}}$ is the first-order activity interaction coefficient of elements $j$ to $i$ relative to the diluted solution. These values are from reference [22]. It should be pointed out that the activity interaction coefficients applied in the present calculations are selected from those measured based on $\mathrm{Fe}-\mathrm{Cr}$-Ni stainless steel hot metal, or those are confirmed applicable for the 18 pct $\mathrm{Cr}-8$ pct Ni stainless steel. In addition, the second interaction coefficients of $\mathrm{Cr}$ and $\mathrm{Ni}$ to the elements in steel are performed because of high $\mathrm{Cr}$ and Ni content in 18 pct $\mathrm{Cr}-8$ pct Ni stainless steel [1,23-25].

$$
\lg f_{\mathrm{i}}=\sum e_{\mathrm{i}}^{\mathrm{j}}[\mathrm{mass} \% \mathrm{j}]+r_{\mathrm{i}}^{\mathrm{Cr}}[\mathrm{Cr} \%]^{2}+r_{\mathrm{i}}^{\mathrm{Ni}}[\mathrm{Ni} \%]^{2}+2 r_{\mathrm{i}}^{\mathrm{Cr}, \mathrm{Ni}}[\mathrm{Cr} \%][\mathrm{Ni} \%]^{2}
$$


Figure 8a,b show the Gibbs free energy change of the foregoing typical chemical reactions with different $\mathrm{Cr}_{2} \mathrm{O}_{3}$ contents in inclusions at $1250{ }^{\circ} \mathrm{C}$. In the two figures, with increasing $\mathrm{Cr}_{2} \mathrm{O}_{3}$ content, the Gibbs free energy increases, and finally are positive, indicating it is more and more difficult to take place for these chemical reactions. The Gibbs free energy for the reaction between $\mathrm{Cr}$ and $\mathrm{MnO}$ is lower than 0 , even if a larger $\mathrm{Cr}_{2} \mathrm{O}_{3}$ content in an inclusion. Moreover, the Gibbs free energy between $\mathrm{Cr}$ and $\mathrm{SiO}_{2}$ is larger than 0 in the case of the amount of $\mathrm{Cr}_{2} \mathrm{O}_{3}$ content larger than 20 mass\%. For the reaction between $\mathrm{Cr}$ and $\mathrm{Al}_{2} \mathrm{O}_{3}$ or $\mathrm{CaO}$, the change of free Gibbs energy is almost positive even if very low $\mathrm{Cr}_{2} \mathrm{O}_{3}$ content in an inclusion. Hence, $\mathrm{Cr}$ is most likely to reduce the $\mathrm{MnO}$ in the inclusion, followed by the $\mathrm{SiO}_{2}$, but $\mathrm{Al}_{2} \mathrm{O}_{3}$ or $\mathrm{CaO}$ in the inclusion is not likely to be reduced by $\mathrm{Cr}$ during heat treatment process. Compared with steel $\mathrm{A}$, inclusions in steel $\mathrm{B}$ are more likely to react with $\mathrm{Cr}$, which accords with the changes of $\mathrm{Cr}_{2} \mathrm{O}_{3}$ in Figure 3.
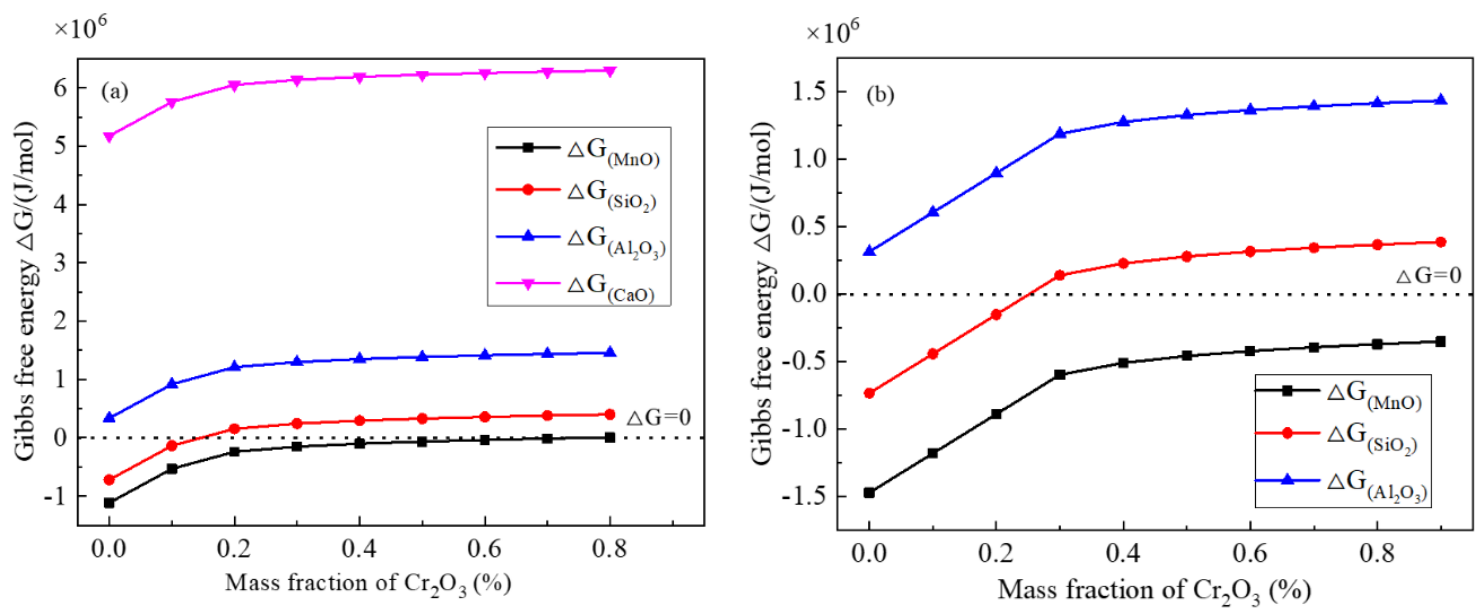

Figure 8. Gibbs free energy changes of some typical possible chemical reactions vs different $\mathrm{Cr}_{2} \mathrm{O}_{3}$ contents in inclusion at soaking temperature $1250{ }^{\circ} \mathrm{C}$ : (a) steel A, (b) steel B.

It is true that some phenomena can be explained by chemical reactions. However, $\mathrm{MnO}$ content increases continuously or is almost not reduced obviously, while $\mathrm{SiO}_{2}$ and even $\mathrm{CaO}$ contents are reduced, as shown in Figure 3. Obviously, this is not in agreement with the thermodynamic results as shown in Figure 8. In addition, if $\mathrm{MnO}-\mathrm{Cr}_{2} \mathrm{O}_{3}$ inclusion is formed due to the chemical reaction Equation (1), the inclusion size would be almost constant but inclusion diameter is changed a lot in present experimental results (Figure 5) as well as in other researchers' results $[14,16]$. Therefore, it can be deduced that there is another driving force to cause inclusion transformation during heat treatment including chemical reactions between $\mathrm{Cr}$ and inclusions.

Ostwald ripening is a very common phenomenon for the secondary phase growth during heat treatment. It is characterized by that the smaller inclusions dissolve, and the larger inclusions grow by absorbing the smaller inclusions during heat treatment. The present observations, such as inclusion size and their population density evolution as shown in Figure 5 and some SEM-mapping images in Figures 6 and 7, accord with the features of Ostwald ripening very well. Therefore, the evolutions of some inclusions during heat treatment mainly follow the rule of Ostwald ripening rather than the chemical reactions.

According the classical Ostwald ripening [26], the interface energy generates with the secondary phase precipitating during heat treatment, and total interface energy would generate when the inclusion with a smaller radius. The driving force of Ostwald ripening is the difference of interface energy between steel matrix and smaller size inclusion and between matrix and larger size inclusion.

In summary, according to the experimental observation and thermodynamic analysis, there are three steps for inclusion evolution during the heat treatment process as schematically shown in Figure 9: (1) $\mathrm{MnO}-\mathrm{Cr}_{2} \mathrm{O}_{3}$ spinel particles precipitate and normal grow; (2) Chemical reactions between $\mathrm{Cr}$ and 
$\mathrm{CaO} / \mathrm{MnO}-\mathrm{SiO}_{2}-\mathrm{Al}_{2} \mathrm{O}_{3}$ inclusion; (3) $\mathrm{CaO} / \mathrm{MnO}-\mathrm{SiO}_{2}-\mathrm{Al}_{2} \mathrm{O}_{3}$ inclusions and $\mathrm{MnO}-\mathrm{Cr}_{2} \mathrm{O}_{3}$ inclusions grow by Ostwald ripening, namely by absorbing smaller $\mathrm{MnO}-\mathrm{Cr}_{2} \mathrm{O}_{3}$ particles.

(1)

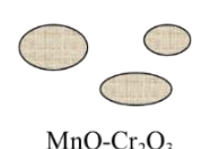

Precipitate and normal grow

$\mathrm{MnO}-\mathrm{Cr}_{2} \mathrm{O}_{3}$

(2)

$\mathrm{Cr}$

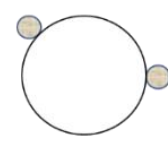

$\mathrm{CaO} / \mathrm{MnO}-\mathrm{SiO}_{2}-\mathrm{Al}_{2} \mathrm{O}_{3}$

(3)

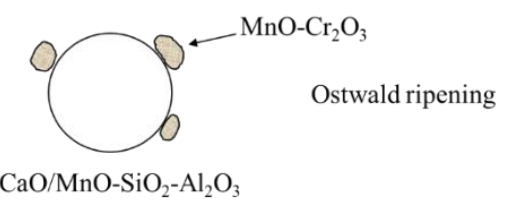

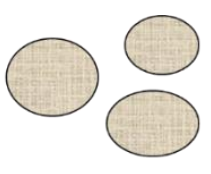

$\mathrm{MnO}-\mathrm{Cr}_{2} \mathrm{O}_{3}$

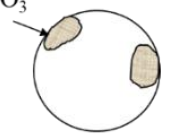

$\mathrm{CaO} / \mathrm{MnO}-\mathrm{SiO}_{2}-\mathrm{Al}_{2} \mathrm{O}_{3}$

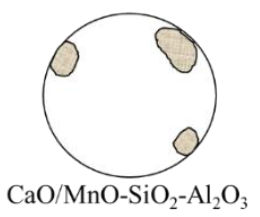

Figure 9. Schematic diagram of three possible evolution processes of the inclusion during the soaking process.

Three steps always take place simultaneously during the heat treatment process, in particular the later two steps are even likely to occur on the same one inclusion. Thus, it is difficult to distinguish quantitively, for which the step is the dominant mechanism for inclusion evolution during the heat treatment process, which is needed further investigated. But as shown in Figure 3, average MnO contents increase or keep almost unchanged which is, obviously, not the effects of the chemical reactions, thus it could conclude that the Ostwald ripening play a very important role on the inclusion modification during heat treatment process.

\section{Conclusions}

Transformations of two common types of nonmetallic inclusion in 304 stainless steel, smelted by high basicity refining slag and low basicity slag, respectively, were investigated in laboratory-scale furnace at $1250^{\circ} \mathrm{C}$. The following conclusions were obtained.

Firstly, the slag system with high basicity of LF results in the formation of $\mathrm{CaO}-\mathrm{SiO}_{2}-\mathrm{Al}_{2} \mathrm{O}_{3}$ inclusions with a high melting point. Moreover, $\mathrm{MnO}-\mathrm{SiO}_{2}-\mathrm{Al}_{2} \mathrm{O}_{3}$ inclusions are mainly formed under slag with low basicity, which are almost in the liquid phase at the heat treatment temperature before rolling.

Secondly, inclusion population density increases at the first stage and then decreases, and their average size firstly decreases and then increases due to a large number of $\mathrm{Cr}_{2} \mathrm{O}_{3}-\mathrm{MnO}$ particles precipitating and their growth during heat treatment process.

Thirdly, there is almost no $\mathrm{Cr}_{2} \mathrm{O}_{3}$ before the heat treatment, but $\mathrm{Cr}_{2} \mathrm{O}_{3}$ precipitates gradually increase along with the heat treatment process. The increasing rate of $\mathrm{Cr}_{2} \mathrm{O}_{3}$ content in $\mathrm{MnO}-\mathrm{SiO}_{2}-\mathrm{Al}_{2} \mathrm{O}_{3}$ inclusion is much higher due to its low melting point. The increasing of $\mathrm{Cr}_{2} \mathrm{O}_{3}$ content in the inclusion would increase their melting points and lower their plasticities.

Finally, both experimental results and thermodynamic analysis show that there are three steps for inclusion evolution during the heat treatment process: (1) many small size $\mathrm{MnO}-\mathrm{Cr}_{2} \mathrm{O}_{3}$ spinel particles precipitate and grow; (2) Chemical reactions between $\mathrm{Cr}$ and $\mathrm{CaO} / \mathrm{MnO}-\mathrm{SiO}_{2}-\mathrm{Al}_{2} \mathrm{O}_{3}$ inclusion; (3) by Ostwald ripening, namely $\mathrm{CaO} / \mathrm{MnO}-\mathrm{SiO}_{2}-\mathrm{Al}_{2} \mathrm{O}_{3}$ inclusions and $\mathrm{MnO}-\mathrm{Cr}_{2} \mathrm{O}_{3}$ inclusions grow by absorbing smaller $\mathrm{MnO}-\mathrm{Cr}_{2} \mathrm{O}_{3}$ particles. Ostwald ripening plays an important role on inclusion evolution during the soaking process. 
Author Contributions: W.-S.Y. analysed the results, and wrote the paper; S.L. supervised and designed the experiments; S.-W.H. and J.-W.W. provided help in calculation; Y.Y. carried out the experimental work; J.G. and H.-J.G. assisted in revising the paper. All authors have read and agreed to the published version of the manuscript.

Funding: This research was funded by the Science and Technology Program of Sichuan Province, China (Grant NO. 18SYXHZ0069), National Science Foundation for Young Scientists of China (5170402), and Fundamental Research Funds for the Central Universities (FRF-TP-20-004A3, FRF-TP-19-030A2, FRF-TP-16-079A1).

Conflicts of Interest: The authors declare no conflict of interest.

\section{References}

1. Huang, F.; Liu, C.; Maruoka, N.; Kitamura, S.-Y. Dissolution behaviour of MgO based refractories in $\mathrm{CaO}-\mathrm{Al}_{2} \mathrm{O}_{3}-\mathrm{SiO}_{2}$ slag. Ironmak. Steelmak. 2015, 42, 553-560. [CrossRef]

2. Park, J.H.; Kang, Y. Inclusions in Stainless Steels- A Review. Steel Res. Int. 2017, 88, 1700130. [CrossRef]

3. Park, J. Thermodynamic investigation on the formation of inclusions containing $\mathrm{MgAl} 2 \mathrm{O} 4$ spinel during 16Cr-14Ni austenitic stainless steel manufacturing processes. Mater. Sci. Eng. A 2008, 472, 43-51. [CrossRef]

4. Lima, E.V.D.O.; Sousa, G.H.; Neto, J.G.C.; Peixoto, J.J.M.; Da Silva, C.A. Thermodynamic Simulations and Industrial Trials Applied to Inclusion Control of SAE 9254 Si-Mn Killed Steel. Met. Mater. Trans. A 2020, 51, 2187-2198. [CrossRef]

5. Li, X.; Long, X.; Wang, L.; Tong, S.; Wang, X.; Zhang, Y.; Li, Y. Inclusion Characteristics in 95CrMo Steels with Different Calcium and Sulfur Contents. Materials 2020, 13, 619. [CrossRef] [PubMed]

6. Suito, H.; Inoue, R. Thermodynamics on Control of Inclusions Composition in Ultra-clean Steels. ISIJ Int. 1996, 36, 528-536. [CrossRef]

7. Zhang, L.; Thomas, B.G. State of the Art in Evaluation and Control of Steel Cleanliness. ISIJ Int. 2003, 43, 271-291. [CrossRef]

8. Bernard, G.; Ribound, P.V.; Urbain, G. Oxide inclusions plasticity. Metall. Res. Technol. 1981, 78, 421-434.

9. Kang, Y.-B.; Lee, H.-G. Inclusions chemistry for Mn/Si deoxidized steels: thermodynamic predictions and experimental confirmations. ISIJ Int. 2004, 44, 1006-1015. [CrossRef]

10. Ren, Y.; Zhang, L.; Fang, W.; Shao, S.; Yang, J.; Mao, W. Effect of Slag Composition on Inclusions in Si-Deoxidized 18Cr-8Ni Stainless Steels. Met. Mater. Trans. B 2016, 47, 1024-1034. [CrossRef]

11. Takahashi, I.; Sakae, T.; Yoshida, T. Changes of the nonmetallic inclusion by heating. Tetsu-to-Hagane 1967, 53, 168-173.

12. Takano, K.; Nakao, R.; Fukumoto, S.; Tsuchiyama, T.; Takaki, S. Grain Size Control by Oxide Dispersion in Austenitic Stainless Steel. Tetsu-to-Hagane 2003, 89, 616-622. [CrossRef]

13. Shibata, H.; Tanaka, T.; Kimura, K.; Kitamura, S.-Y. Composition change in oxide inclusions of stainless steel by heat treatment. Ironmak. Steelmak. 2010, 37, 522-528. [CrossRef]

14. Shibata, H.; Kimura, K.; Tanaka, T.; Kitamura, S.-Y. Mechanism of Change in Chemical Composition of Oxide Inclusions in Fe-Cr Alloys Deoxidized with Mn and Si by Heat Treatment at 1473 K. ISIJ Int. 2011, 51, 1944-1950. [CrossRef]

15. Taniguchi, T.; Satoh, N.; Saito, Y.; Kubota, K.; Kumagai, A.; Tamura, Y.; Miki, T. Investigation of Compositional Change of Inclusions in Martensitic Stainless Steel during Heat Treatment by Newly Developed Analysis Method. ISIJ Int. 2011, 51, 1957-1966. [CrossRef]

16. Ren, Y.; Zhang, L.; Pistorius, P.C. Transformation of Oxide Inclusions in Type 304 Stainless Steels during Heat Treatment. Met. Mater. Trans. A 2017, 48, 2281-2292. [CrossRef]

17. Guo, J.; Chen, X.-R.; Han, S.-W.; Yan, Y.; Guo, H.-J. Evolution of plasticized MnO-Al2O3-SiO2-based nonmetallic inclusion in $18 \mathrm{wt} \% \mathrm{Cr}-8 \mathrm{wt} \% \mathrm{Ni}$ stainless steel and its properties during soaking process. Int. J. Miner. Met. Mater. 2019, 27, 328-339. [CrossRef]

18. Jung, I.-H.; Decterov, S.A.; Pelton, A.D. Computer Applications of Thermodynamic Databases to Inclusion Engineering. ISIJ Int. 2004, 44, 527-536. [CrossRef]

19. Imani, R.; Dillert, R.; Bahnemann, D.W.; Pazoki, M.; Apih, T.; Kononenko, V.; Repar, N.; Kralj-Iglič, V.; Boschloo, G.; Drobne, D.; et al. Multifunctional Gadolinium-Doped Mesoporous TiO2 Nanobeads: Photoluminescence, Enhanced Spin Relaxation, and Reactive Oxygen Species Photogeneration, Beneficial for Cancer Diagnosis and Treatment. Small 2017, 13, 1700349. [CrossRef] 
20. Cao, Y.; Li, G.; Hou, Y.; Moelans, N.; Guo, M. DFT study on the mechanism of inclusion-induced initial pitting corrosion of Al-Ti-Ca complex deoxidized steel with Ce treatment. Phys. B: Condens. Matter 2019, 558, 10-19. [CrossRef]

21. The Japan Society for the Promotion of Science. Steelmaking Data Sourcebook; Gordon \& Breach Science Publishers: New York, NY, USA, 1988; p. 1181.

22. Guo, H.J. Metallurgical Physical Chemistry, 2nd ed.; Metallurgical Industry Press: Beijing, China, 2013 ; p. 113.

23. Suzuki, K.; Ban-Ya, S.; Hino, M. Deoxidation Equilibrium of Chromium Stainless Steel with Si at the Temperatures from 1823 to 1923 K. ISIJ Int. 2001, 41, 813-817. [CrossRef]

24. Suzuki, K.; Ban-Ya, S.; Hino, M. Deoxidation Equilibrium of Cr-Ni Stainless Steel with Si at the Temperatures from 1823 to $1923 \mathrm{~K}$. ISIJ Int. 2002, 42, 146-149. [CrossRef]

25. Ohta, H.; Suito, H. Calcium and Magnesium Deoxidation in Fe-Ni and Fe-Cr Alloys Equilibrated with $\mathrm{CaO}-\mathrm{Al} 2 \mathrm{O} 3$ and $\mathrm{CaO}-\mathrm{Al} 2 \mathrm{O} 3-\mathrm{MgO}$ Slags. ISIJ Int. 2003, 43, 1293-1300. [CrossRef]

26. Lifshitz, I.; Slyozov, V. The kinetics of precipitation from supersaturated solid solutions. J. Phys. Chem. Solids 1961, 19, 35-50. [CrossRef]

Publisher's Note: MDPI stays neutral with regard to jurisdictional claims in published maps and institutional affiliations.

(C) 2020 by the authors. Licensee MDPI, Basel, Switzerland. This article is an open access article distributed under the terms and conditions of the Creative Commons Attribution (CC BY) license (http://creativecommons.org/licenses/by/4.0/). 